\title{
脳血管障害後遗症例の尿路感染症に関する 臨床細菌学的研究
}

\author{
順天堂大学医学部臨床病理学教室 \\ 岡田淳
}

(昭和55年11月 26 日受付)

（昭和56年 1 月 13 日受理）

Key words: Urinary tract infections, Sequelae of cerebrovascular disorders, Bedridden

\begin{abstract}
要旨
老年者特に寝たきり老人の尿路感染症は無症候性のことが多く, 混合感染を伴つて難治性となる傾向がある とされている．著者は，1974～1979年の 6 年間に脳血管障害後遺症で入院中に 尿路感染症を合併した患者638 例を対象に臨床細菌学的検討を行ない, $2 \sim 3$ の知見を得た.

1.のべ1267回の尿培養で, 1901株の細菌が分離され, 主要菌種は E.coli, Klebsiella, Proteus 群で, グラ ム陰性桿菌が全体の $90 \%$ を占めた。分離菌の年次推移をみると, Proteus 群ことにインドール陽性 Proteus の 増加が著しかつた. 又混合感染は約45\%にみられた。

2. 薬剂感受性試験の成績では年々耐性化傾向がみられ, 分離頻度の高いProteus で各種薬剂に多剂耐性 を示した. 又化学療法剤投与による治療成績では，一部の菌株に菌数执よび菌種の変化がみられた。

3. 女性の難治性尿路感染症患者を対象に腔内細菌培養を試みた結果，多菌種の細菌が分離され，腟内の normal flora に加えて, いわゆる opportunistic pathogen も少なからず忍められた。これらの成績から脳血 管障害後遺症例に合併した尿路感染症の治療に際しては, 耐性菌による菌交代を考慮し, 滴切な化学療法剤を 選択することが第一であるが，抢むつによる污染を避けるため，局所の清潔を保つこ同時に，女性患者では胵 内洗浄の実施も，尿路感染防止の有効な手段之考觉られた。
\end{abstract}

\section{I. はじめに}

近年, 老年人口の増加に伴い脳血管障害执よび その後遺症患者を対象とした病院や施設が急増し ているなかで，尿路感染症はこれらの疾患の合併 症あるいは二次感染症としてもつとも発生頻度の 高い疾患にあげられ，老人医療の問題提起の一つ となつている事実は周知のところである.

老人の 尿路感染症に 関しては諸家の 多数の報 告 ${ }^{1) ~ 6)}$ があるが，脳血管障害者に合併した尿路感 染症に関する報告は少ない。

別刷請求先 : (广 108) 港区三田 1-4-3 日本専売公社東京病院岡田淳
著者は，主として脳血管障害後遺症で寝たきり の老年者を対象に，1974年から1979年の 6 年間に 打忷子尿路感染症の発生頻度, 原因菌, 薬剤感受 性，治療などについて臨床細菌学的見地から検討 した。

\section{II. 対象ならびに方法}

1. 対象

対象は多摩成人病研究所付属厚生荘病院に主々 して脳血管障害扣よびその後遺症で長期入院中の 60歳から90歳の患者638例（男性159例，女性479 例, 平均 $75 \pm 8$ 歳) である.

2. 方法 
1）調査方法

調查は下記に示すごとくに行つた。

$$
\begin{aligned}
& \begin{array}{c}
\text { 調査対象群 } \\
\downarrow \\
\text { 自覚症状の有無, 尿一般検査 }
\end{array} \\
& \text { 尿道カテーテルで採尿 } \\
& \text { 尿中白血球数 細菌塗抹検查 } \\
& \text { 算定 } \\
& \text { 細菌数 } \geqq 10^{5} / \mathrm{ml} \text { の尿について } \\
& \text { 菌の分離同定検査 } \\
& \text { 薬剂感受性試験 } \\
& \text { 治療が必要な症例について } \\
& \text { 化学療法 } \\
& \downarrow \\
& \text { 効果判定 }
\end{aligned}
$$

\section{2）検查方法}

尿一般検査で，尿沈渣中に白血球が 鏡検（ $\times$ 400）下で毎視野10個以上認められた例执よび臨 床症状で尿路感染が疑われた例につき，男女共に カテーテルで尿を採取した。

被検尿の一部は遠沈し, 沈椬中の白血球々細菌 （グラム染色）を鏡検し，有意な細菌尿と考えら れる例の尿について血液平板培地, BTB 乳糖寒 天培地に培養し, 発育した集落について生物学的 検査を行い菌種を同定した.

又, 生菌数の測定は尿をよく混和し，午の一定 量をトリプトソイ寒天培地に混釈培養し, 発育し た集落数より尿 $1 \mathrm{ml}$ 中の細菌数を算定した。

薬剂感受性試験は下記に 示す 10 種の薬剤につ いて，ハートインフュージョン寒天培地を用いて 1 濃度ディスク法によつて行ない（一（十）を 耐性，(H) (H) を感性とした.：Ampicillin (ABPC),Cephaloridine (CER), Tetracycline (TC), Chloramphenicol (CP), Erythromycin (EM), Kanamycin (KM), Gentamicin (GM), Dibekacin (DKB), Colistin (CL), Nalidixic acid (NA).

尿中白血球については尿沈椬鏡検 $(\times 400)$ に 扣ける個数より次の様な分類基準を設けた。即ち 毎視野 1 〜 9 個を土，10～19個を十，20〜29個を H，30個以上を卅とした。

3）治療方法

尿路感染症を疑わせる臨床所見のあるもののら
ち, 治療が必要と判断された例について, 薬剤感 受性試験で感性を示した薬剤を $1 \sim 14$ 日間投与 し，その治療効果をみた。治療に用いた薬哓の種

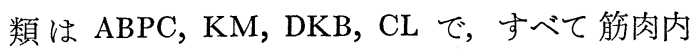
注射によつた。

\section{III. 成 績}

1. 尿中細菌の分離状況

1974年から1979年の 6 年間に括いて延べ1267例 の老年者の尿から，1901株の細菌を分離した。

分離された細菌の内訳は Table 1 に示すごとく で, 総株数1901株のうちグラム陰性桿菌をみると, E. coli が483株, インドール陽性 Proteus が411株, インドール陰性 Proteus が306株, Klebsiella が 261株, Pseudomonas aeruginosa が 103株で, グ

\begin{tabular}{|c|c|c|c|}
\hline Organism & $\begin{array}{c}\text { No.of } \\
\text { strains }\end{array}$ & $\begin{array}{l}\text { Isolation } \\
\text { rate }(\%)\end{array}$ & $\begin{array}{c}\% \text { of } \\
\text { cultures } \\
\text { positive* }\end{array}$ \\
\hline Staph.aureus & 71 & 3.7 & 5.6 \\
\hline Str.faecalis & 123 & 6.3 & 9.7 \\
\hline E.coli & 483 & 25.4 & 38.1 \\
\hline Klebsiella & 261 & 13.7 & 20.6 \\
\hline Proteus (indole -) $* *$ & 306 & 16.1 & 24.1 \\
\hline Proteus(indole + ) $* k *$ & 411 & 21.6 & 32.4 \\
\hline Ps.aeruginosa & 103 & 5.7 & 3.1 \\
\hline others & 143 & 7.5 & 11.3 \\
\hline Total & 1901 & 100 & \\
\hline
\end{tabular}
ラム陰性桿菌が総株数の $82.5 \%$ を占めた。一方, 球菌は Streptococcus faecalis 123株, Staphylococcus aureus 71 株で, 総株数の $10.1 \%$ あつた.

分離頻度の高い順に菌種を並べると，E.coli> インドール陽性 Proteus 群>インドール陰性 Proteus $>$ Klebsiella $>$ Str. faecalis $>$ Ps. aeruginosa $>$ Staph. aureus となつた.さらに，297例につい て菌の混在状況をみると Table 2 に示すごとくで

Table 1 Numbers and percentage of microorganisms isolated from 1267 urinary cultures

Table 2 Mixed infections in 297 urinary tract infections

\begin{tabular}{ccc}
\hline $\begin{array}{c}\text { No.of } \\
\text { bacteria }\end{array}$ & $\begin{array}{r}\text { No.of } \\
\text { cases }\end{array}$ & Frequency(\%) \\
\hline one & 165 & 55.6 \\
two & 108 & 36.4 \\
$\begin{array}{c}\text { three or } \\
\text { more }\end{array}$ & 24 & 8.0 \\
\hline
\end{tabular}


ある. 分離培養で 1 菌種のみが検出された例は 55.6\%で，その内訳は E. coli 21.9\%, Proteus mirabilis $12.5 \%$, Klebsiella 7.7\%などであつた.

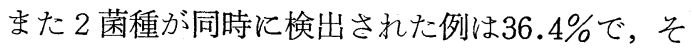
の主な組合せは E. coli と Klebsiella, E. coli と Pr. mirabilis, Staph. aureus $と$ Pr. mirabilis であつた。ささらに，3種以上が同時に検出された 例は $8 \%$ で，その組合せでは Proteus, Ps. aeruginosa, Klebsiella, E. coli が主体をなしていた.

2. 歩行状態と尿路感染症発生頻度および細菌 分離状況

脳血管障害预よびその 後遺症の 老人患者339例 を, 単独歩行可能例 (111例), 介助なくしては歩 行不可能な歩行困難例 (39例) 沶よび尿便失禁の ためオムツ使用のいわゆる寝たきりの歩行不可能 例（189例）飞大別した。尿路感染症の 発生頻度 は Table 3 に示すごとく, 歩行可能例で $14.6 \%$, 歩行困難例で $23.1 \%$, 寝たきり例で $69.3 \%$ に認め られ，これを同地域の 健常成人(155例)と比較す

Table 3 Incidence of urinary tract infection of the aged

\begin{tabular}{lccc} 
Condition of the gait & $\begin{array}{c}\text { Average } \\
\text { age }\end{array}$ & $\begin{array}{c}\text { No.of } \\
\text { cases }\end{array}$ & Frequency(\%) \\
\hline Normal control(healthy adults) & 42 & 155 & 2.6 \\
\hline Patient group : & 75 & 111 & 14.6 \\
Normal (not disturbed) & 74 & 39 & 23.1 \\
Difficult & 73 & 189 & 69.3 \\
\hline Impossible(bedridden) &
\end{tabular}

Table 4 Incidence of microorganisms isolated from 222 Urinary cultures of the aged patients with disturbance in the gait

\begin{tabular}{|c|c|c|c|}
\hline \multirow[b]{2}{*}{ Organism } & \multicolumn{3}{|c|}{ disturbance in the gait } \\
\hline & $\begin{array}{l}\text { none } \\
(111) *\end{array}$ & $\begin{array}{l}\text { difficult } \\
\text { in the gait } \\
\text { (39) }\end{array}$ & $\begin{array}{c}\text { bedridden } \\
\text { (189) }\end{array}$ \\
\hline $\begin{array}{l}\text { Staph.aureus } \\
\text { Staph.epidermidis }\end{array}$ & 2.4 & $4.2 \% * *$ & \\
\hline B-Streptococcus & & 4.2 & 0.9 \\
\hline Str.faecalis & 2.4 & 4.2 & 2.7 \\
\hline $\begin{array}{l}\text { E.coli } \\
\text { Klebsiella }\end{array}$ & 4.8 & 16.7 & 23.0 \\
\hline Klebsiella & 2.4 & 8.3 & 12.4 \\
\hline Pr.mirabilis & 1.2 & & 25.7 \\
\hline Pr.vulgaris & & & 2.7 \\
\hline Pr.morganii & & & 4.4 \\
\hline Pr.inconstans & & & 1.8 \\
\hline En.cloacae & & & 2.7 \\
\hline Citrobacter & & & 0.9 \\
\hline Ps.aeruginosa & & & 1.8 \\
\hline others & & & 1.8 \\
\hline $\begin{array}{l}\text { No.of positive } \\
\text { cultures }\end{array}$ & $16(14.6 \%)$ & $9(23.1)$ & $130(69.3)$ \\
\hline$\frac{\text { culcures }}{\text { Average No.of }}$ & & & \\
\hline organisms (/case) & 1.2 & 1.3 & 1.7 \\
\hline
\end{tabular}

ると, 歩行可能例で5.6倍, 歩行困難例で8.9倍, 葠 たきり例で26.7倍の高い頻度を示し，とくに寝た きり老年者で高率に尿路感染症が認められた $\left(\mathrm{X}^{2}\right.$ 検定で $\mathrm{p}<0.01)$. さらに339例の老年者について 歩行状態別に尿中細菌の分離状況をみると(Table 4 ), 歩行可能老年者 (111例) 特よび歩行困難例 (39例) では，グラム陰性桿菌の占める割合が64 〜67\%であつたが，寝たきり例 (189例) では， グラム陰性桿菌が分離菌全体の約 $96 \%$ 占め, グ ラム陽性球菌の占める割合は $4 \%$ にすぎなかつ た. 菌種でみると, 歩行可能例と歩行困難例では グラム陰性桿菌のうち E. coli が主体であつた が，寝たきり例は Proteus が主体をなし，E coli， Klebsiella など多菌種に及んだ.

又, 分離培養で 細菌陽性 $\left(10^{5} / \mathrm{ml}\right.$ 以上) を呈 した 1 例あたりの平均分離菌種数は, 歩行可能例 で1.2種, 歩行困難例で1.3種, 寝たきり例で1.7 種と, 寝たきり例に分離菌種数の 増加を認めた (Mean士S.D. の差の検定で $\mathrm{p}<0.05$ ).

3. 寝たきり老年者に抢ける膝関節運動機能と 尿路尿路感染症発生頻度扣よび細菌分離状況

寝たきり老年者189名の膝関節運動機能の障害 度を関節角度域測定器を用いてつぎのように大別 し, 尿路感染症の発生頻度を比較した. 即ち, 関節 可動域が 105 101度を軽度拘縮群 (slightly contractured group), 100 51度を中等度拘縮群（moderately contractured group), 50〜 6 度を重度拘縮 群 (severely contractuled group), $5 \sim 0$ 度を強直 群 (rigidity group) とした。これらとは別に弛緩 性麻痺群 (flaccid paralysed group) を分けた。そ の結果 Fig. 1 に示すように, 軽度拘縮群 (123例)

Fig. 1 Relationship between motor disturbance of kneejoint and incidence of UTI of bedridden patient

\begin{tabular}{|c|c|c|c|}
\hline & $\begin{array}{l}\text { No. of } \\
\text { cases }\end{array}$ & 50 & $100(\%)$ \\
\hline $\begin{array}{c}\text { Contractured group } \\
\text { slight }\end{array}$ & 123 & WIIIIIITITIITITIIS: & \\
\hline moderate & 30 & Wh & $76.6 \%$ \\
\hline severe & 7 & МाIIIIIIIIIIIIII & $85.7 \%$ \\
\hline Rigidity gruop & 12 & VIIIIIIIIIIIIIIIIIII & $85.3 \%$ \\
\hline $\begin{array}{l}\text { Flaccid paralysed } \\
\text { group }\end{array}$ & 17 & & $\overline{W I}$ 94.1\% \\
\hline
\end{tabular}


Table 5 Incidence of microorganisms isolated from 189 urinary cultures of the bedridden patients

\begin{tabular}{|c|c|c|c|}
\hline Organism & $\begin{array}{l}\text { slightly } \\
\text { contactured } \\
\text { group } \\
(123) \div\end{array}$ & $\begin{array}{l}\text { moderately } \\
\text { cont ractured } \\
\text { group } \\
(30) \\
\end{array}$ & $\begin{array}{l}\text { other } \\
\text { groups } * * \\
\text { (36) }\end{array}$ \\
\hline
\end{tabular}

\section{Staph.aureus}

Staph.epidermidis

B-Streptococcus $1.5 \%$ **\%

Str.faecalis

E.coli

Klebsiella

Pr.mirabilis

Pr.vulgatus
Pr.morganii

Pr.inconstans

En. cloacae
Citrobacter

Ps:aeruginosa

others

No. of positive

cultures

Average No. of
organisms (/case)

\begin{tabular}{rrc}
1.5 & & 8.3 \\
3.1 & & 41.7 \\
18.5 & 25.0 & 16.7 \\
10.8 & 13.9 & 66.7 \\
10.8 & 38.9 & \\
1.5 & 5.6 & 8.3 \\
3.1 & 5.6 & 8.3 \\
1.5 & & 8.3 \\
3.1 & & 8.3 \\
1.5 & 2.8 & $27(75.0)$ \\
1.5 & $14(46.7)$ & 2.3 \\
1.5 & 1.9 & 2 \\
\hline $51(41.5 \%)$ & & \\
1.4 & &
\end{tabular}

* Samples examined, ** include severe contractured group, rigidity group, and flaccid paralysed group, $* * *$ Percentage of cultures positive

Table 6 Annual frequency of microorganisms isolated from urinary cultures of the aged

\begin{tabular}{l|cccccc}
\multicolumn{1}{c|}{ Year } & 1974 & 1975 & 1976 & 1977 & 1978 & 1979 \\
\hline Samples examined & 100 & 75 & 131 & 106 & 107 & 119 \\
\hline Staph.aureus & $12 \%$ & $4 \%$ & $9 \%$ & $6 \%$ & $10 \%$ & $9 \%$ \\
Str.faecalis & 11 & 8 & -8 & -3 & -13 & -11 \\
\hline E.coli & 32 & 36 & 39 & 46 & 33 & 39 \\
Klebsiella & 25 & 23 & 25 & 22 & 19 & 19 \\
Proteus(indole -) & 33 & 35 & 32 & 26 & 26 & 17 \\
Proteus(indole +) & 18 & 26 & 28 & 33 & 39 & 34 \\
Ps.aeruginosa & 2 & 3 & 4 & 6 & 9 & 12 \\
others & 17 & 8 & 10 & 5 & 7 & 8 \\
\hline Average No. of & 1.6 & 1.6 & 1.5 & 1.5 & 1.6 & 1.5 \\
\hline \multicolumn{1}{c}{ organisms } & & & & & & \\
\hline
\end{tabular}

における発生頻度は61.8\%であつたのに比べ，中 等度拘縮群 (30例) では76.6\%, 重度拘縮群 (7 例）では85.7\%，強直群 (12例) では85.3\%，弛 緩性麻痺群(17例)では94.1\%であつた。また各群 に扣ける尿中分離菌の割合をみると（Table 5 )， 軽度拘縮群では E. coli が最も多く, Klebsiella, Pr. mirabilis がこれに次いだ。一方膝関節運動機 能障害の進行につれて Pr. mirabilis を主とする Proteus 群の分離頻度が高くなり, 重度拘縮, 強 直，弛緩性麻痺群を含む36例では Proteus 群は 約 $80 \%$ の例で分離された. また平均分離菌種数も 運動機能障害の進行につれて増加する傾向がみら れ, 軽度拘縮群, 中等度拘縮群扎よびその他の群 でそれぞれ，1.4種，1.9種，2.3種であつた。

4. 分離菌の年次推移
主要分離菌の年度別分離状況をTable 6 に示す. 1974年に和ける主な細菌の分離頻度をみると，イ ンドール陰性 Proteus が首位を占め, 次いで E. coli $>$ Klebsiella>インドール陽性 Proteus であつ た. 1975～1976年では E. coli が首位を占め，イ ンドール陰性 Proteus>インドール陽性 Proteus > Klebsiella の順を示した. 1977年は E. coli>イ ンドール陽性 Proteus>インドール陰性 Proteus > Klebsiella で，1978年はインドール陽性 Proteus が首位となり E. coli, Proteus >Klebsiella の順 であつた。 1979年に和いては，E．coli>インド ール陽性 Proteus $>$ Klebsiella $>$ イ ドール陰性 Proteus の順を示し，6年間を通して，分離頻度 の順位に一定の傾向はみられなかつた。

分離頻度の 年次推移に変化を認めた E. coli, Klebsiella, インドール㓌性 Proteus, インドール 陽性 Proteus, Ps. aeruginosa は Fig. 2 に示すご

Fig. 2 Annual changes in aerobic Gram negative rods isolated from urine

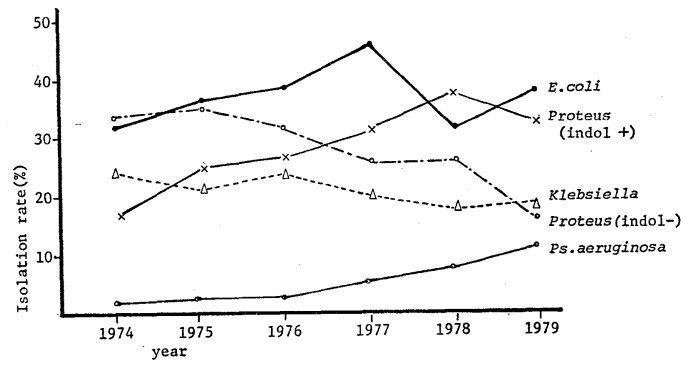

とく，インドール陽性 Proteus と Ps. aeruginosa は年毎に分離頻度に増加がみられ, 一方, イン ドール陰性 Proteus と Klebsiella では分離頻度 に減少傾向がみられた。また，E．coli は1975年 から1977年にかけて 分離頻度に増加をみたが， 1978年に一過性の減少を認めた。な牧，平均分離 菌種数は1974年から1979年にかけて1.5ないし1.6 種で，年次的に有意差はみられなかつた。

5. 化学療法剤の使用状況

主に脳血管障害およびその後遺症患者を対象と した化学療法剤の使用状況を Fig. 3 に示した. 1974年では CP が最も使用頻度が高く使用薬 
Fig. 3 Changes in dosage of antimicrobial agents

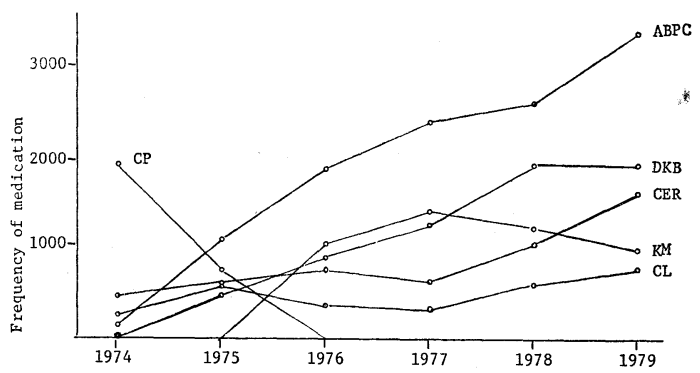

剂全体の約75\%を占めたが，1975年からは ABPC の使用量に増加がみられ, CP の使用量は激減し た。さらに1976年からは CP は使用されなくな り，ABPC の使用量が全体の39\%を占め，KM， DKB がこれに次いだ. 1977年も1976年同様に上 記 3 剂の 使用量に増加がみられた。1978年には $\mathrm{ABPC}$ および DKB の使用量が増加し，これら 2 種の薬剤が占める割合は62\%であつた。 1979 年では $\mathrm{ABPC}$ と CER の使用量が増加し, 使用 頻度は $\mathrm{ABPC}>\mathrm{DKB}>\mathrm{CER}>\mathrm{KM}>\mathrm{CL}$ の順であ つた。また，1974年に比へ，1979年の化学療法剤 使用量は ABPC 31倍, CER 5 倍, DKB 359倍, CL 4 倍であつた.

6. 薬剤感受性の年次変化

1974年から1979年にかけて，老年者の尿から 分離された E. coli, Klebsiella, インドール陰性 Proteus, インドール陽性 Proteus の ABPC, CER, $\mathrm{CP}, \mathrm{KM}, \mathrm{DKB}, \mathrm{CL}$ に対する感性率の年次推移 を調査した (Fig. 4).

1) E. coli :

(1) ABPC の感性率は1974 1975年 (66.2\%), 1976１977年（55.0\%)，1978年 $(66.0 \%) ， 1979$ 年 $(62.5 \%)$ で, 1974〜1975年に比べ, 1976〜1977 年の感性率に $11.2 \%$ の減少（耐性株の増加）がみ られた。

(2) CER は1974〜1975年 $(78.4 \%), 1976 \sim 1977$ 年 $(69.8 \%) ， 1978$ 年 $(85.7 \%), 1979$ 年 $(85.6 \%)$ で，1974〜1975年に比べ，1976〜1977年で 8.6\% の耐性株の増加を認めた.

(3) CP は1974〜1975年 $(60.6 \%) ， 1976 〜 1977$
Fig. 4 Changes of antimicrobial susceptibility (*No. of strains)
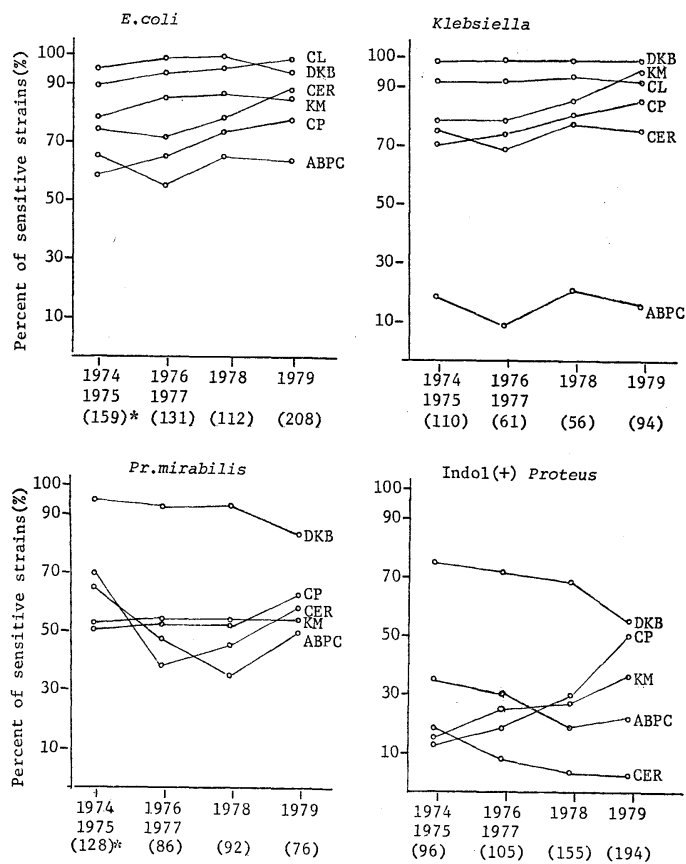

年 $(65.9 \%) ， 1978$ 年 $(77.7 \%), 1979$ 年 $(77.9 \%)$ で，1974１975年に比べ，1979年で17.3\%の感性 株の増加がみられた。

な拈，KM，DKB，CL の 感性率には年次的に 大きな変化は認められず，80\%以上の株は感性で あつた。

2) Klebsiella:

(1) ABPC の感性率は1974 1975年 (18.2\%), 1976１977年（13.0\%)，1978年 (21.8\%)，1979 年 $(17.0 \%)$ で，1978年を除き $80 \%$ 以上の株が耐 性であつた。

(2) CER は1974 1975年 $(75.0 \%), 1976 \sim 1977$ 年 $(69.6 \%), 1978$ 年 $(80.4 \%), 1979$ 年 $(74.5 \%)$ で, 各年度とも感性株が70〜80\%を占めた。

(3) CP は1974 1975年 $(70.9 \%), 1976 \sim 1977$ 年 $(70.5 \%), 1978$ 年 $(80.4 \%), 1979$ 年 $(85.1 \%)$ で，1974〜1975年と比較すると，1979年で感性株 の増加が $14.2 \%$ にられた。

(4) $\mathrm{KM}$ は1974 1975年 $(78.1 \%), 1976 \sim 1977$ 年 $(78.7 \%), 1978$ 年 $(82.1 \%), 1979$ 年 $(93.6 \%)$ 
Fig. 5 Percentage of susceptible strains to various antimicrobial agents
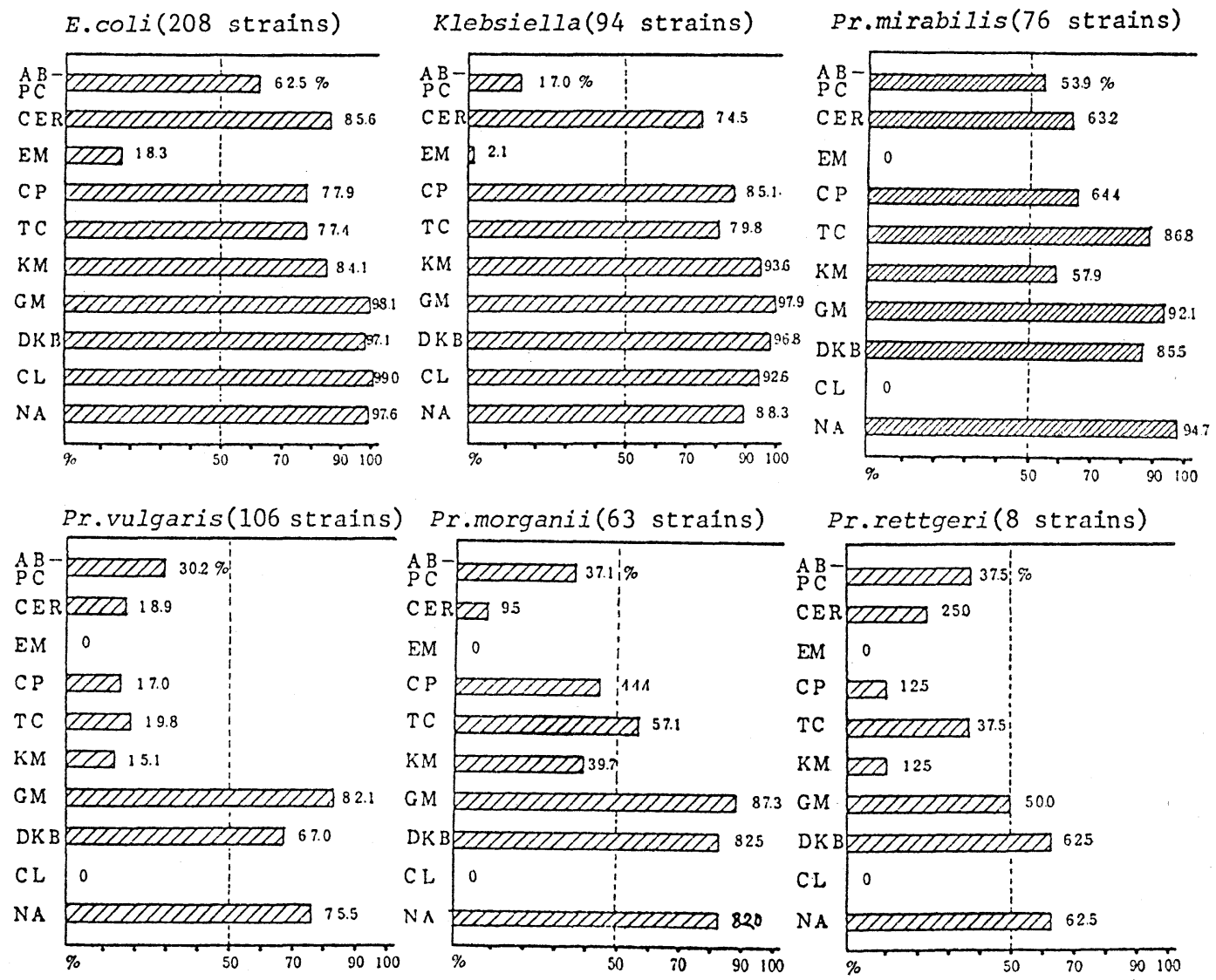

Pr.rettgeri(8 strains)

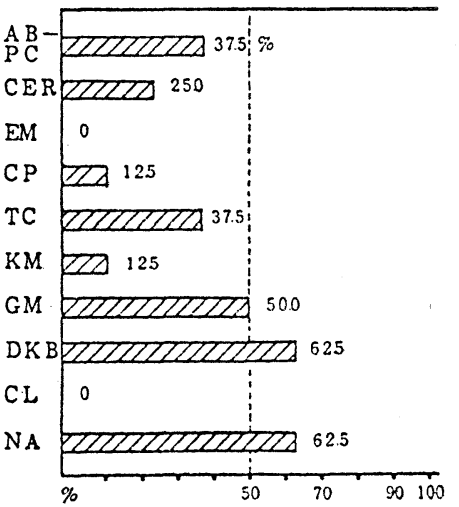

Pr.inconstans(21 strains) Ps.aeruginosa(126 strains)
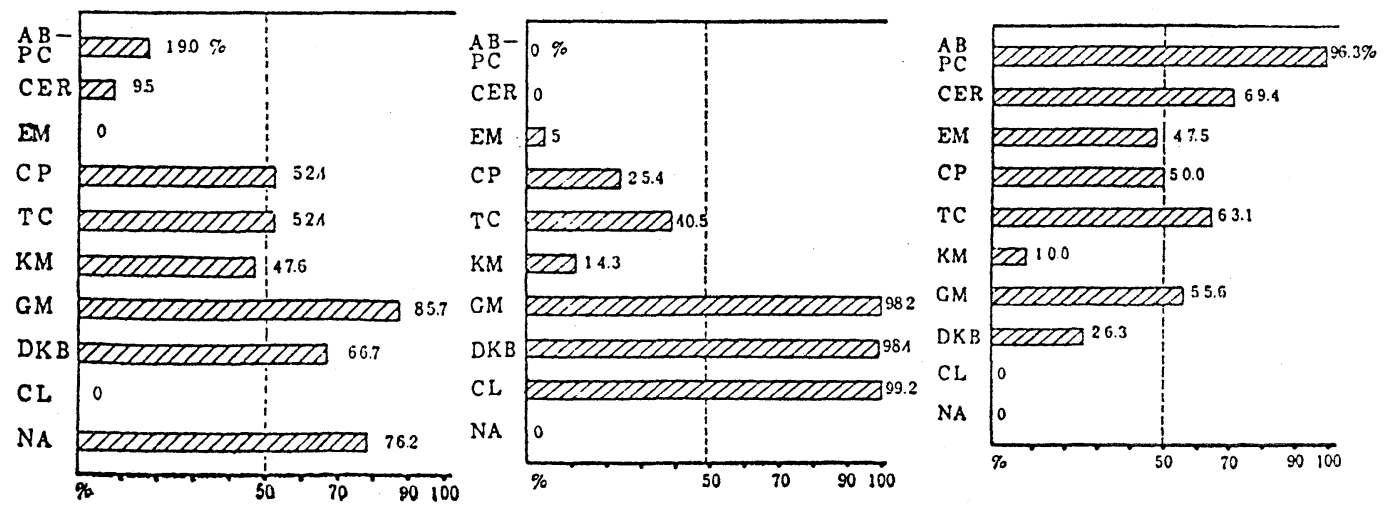
で，1974～1975年に比べ1979年で15.5\%の感性株 の増加がみられた。

な扣，DKB の感性率は年次的に大きな変化な く, 90\%以上の株は感性であつた。

3）インドール陰性 Proteus (Proteus mirabils) :

(1) ABPC の感性率は1974〜1975年 (66.8\%), 1976１977年（50.0\%)，1978年 (43.5\%)，1979 年 $(53.9 \%)$ で，1974〜1975年に比べ，1976〜 1977年で16.8\%，1978年で23.3\%，1979年で 12.9 \%の耐性株の増加を認めた。

(2) CER は1974 1975年 $(70.4 \%), 1976 \sim 1977$ 年 $(45.3 \%), 1978$ 年 $(47.8 \%), 1979$ 年 $(63.2 \%)$ で，1974～1975年に比べ1976〜 1977年で25.1\%， 1978年で22.6\%の耐性株の増加がみられた。

(3) CP は1974 1975年 $(51.9 \%), 1976 \sim 1977$ 年 $(53.3 \%), 1978$ 年 $(50.0 \%), 1979$ 年 $(64.4 \%)$ で，1974～1975年に比べ1979年で12.5\%の感性株 の増加を認めた。

(4) DKB は1974 1975年 $(91.7 \%), 1976 \sim 19$ 77 年 $(95.0 \%) ， 1978$ 年 $(92.2 \%) ， 1979$ 年 (85.5 \%) で，1974１975年に比べ1978年で11.6\%の耐 性株の増加が認められた。

なお，KM の感性率は年次的に大きな変化は 見られず，50〜60\%の株は感性であつた。 また， CL にはすべての株が耐性であつた。

4）インドール陽性 Proteus (Pr. vulgaris, Pr. morganii, Pr. rettgeri, Pr. inconstans):

(1) ABPC の感性率は1974 1975年 (34.8\%), 1976１977年 (28.8\%)，1978年 (21.3\%)，1979 年 $(25.3 \%)$ で1974 1975年に比べ1978年で13.5 \%の耐性株の増加を認めた。

(2) CER は1974 1975年に扮いて感性率が 19.7\%であつたが, 1976〜1977年で8.6\%と，11.1 \%の耐性株の増加がみられ，以後1979年まで耐性 株が90\%以上を占めた。

(3) CP の感性率は 1974～1975年 (15.2\%), 1976～1977年 (21.9\%)，1978年 (24.5\%)，1979 年 $(49.0 \%)$ で，1974 1975年に比べ 1979年で $26.8 \%$ の感性株の増加が認められた。
(4) KM は 1974〜1975年 $(18.2 \%) ， 1976 \sim 19$ 77 年 $(25.7 \%) ， 1978$ 年 $(23.8 \%) ， 1979$ 年 (36.6 \%) で，1974〜1975年に比べ1979年で18.4\%の感 性株の増加を呈した。

(5) $\mathrm{DKB}$ は1974 1975年 $(75.0 \%), 1976 \sim 1977$ 年 $(74.0 \%), 1978$ 年 $(70.3 \%), 1979$ 年 $(55.7 \%)$ で1974〜1975年に比べ1979年で19.3\%の耐性株の 増加がみられた。

なお，CL にはすべての株が耐性であつた。

7. 菌種別薬剂感性率

1979年に老年者の尿より分離された E. coli (208株), Klebsiella (94株), Pr. mirbilis (76株), Pr. vulgaris (106株), Pr. morganii (63株), Pr. rettgeri ( 8 株), Pr. inconstans (21株) と1974〜 1979年に分離された Ps. aeruginosa (126株), Str. faecalis (160株)の薬剂感性率を Fig. 5 亿示した.

1） E. coli : E. coli の90\%以上が高い感性を 示した薬剤は $\mathrm{GM}, \mathrm{DKB}, \mathrm{CL}, \mathrm{NA}$, 次いで70 89\%の株が感性であつた薬剤は CER，CP，TC， $\mathrm{KM}$ で, $\mathrm{CL}>\mathrm{GM}>\mathrm{NA}>\mathrm{DKB}>\mathrm{CER}>\mathrm{KM}>\mathrm{CP}$ $>\mathrm{TC}$ の感性順を示し, $\mathrm{ABPC}$ には $38 \%$ の株が耐 性，EM は82\%の株が耐性であつた。

2）Klebsiella：90\%以上の 株が 感性を示した 薬剂は $\mathrm{KM}, \mathrm{GM}, \mathrm{DKB}, \mathrm{CL}$ 次いで70〜89\%の 株が感性を示した薬剤は CER, CP, TC, NA で, $\mathrm{GM}>\mathrm{DKB}>\mathrm{KM}>\mathrm{CL}>\mathrm{NA}>\mathrm{CP}>\mathrm{TC}>\mathrm{CER}$ の 感性順を示し, $\mathrm{ABPC}$ と $\mathrm{EM}$ に対しては耐性株 の出現が多かつた。

3）Pr. mirabilis：高い感性を示した薬剤は GM，NA，次いで70～89\%の株が感性であつた薬 剤は $\mathrm{TC}, \mathrm{DKB} て ゙, \mathrm{NA}>\mathrm{GM}>\mathrm{TC}>\mathrm{DKB}$ の感 性順を示し， ABPC，CER，KM には40〜 50\% の株が，EM，CL にはすべての株が耐性であつ た。

4）Pr. vulgaris：高い感性を示した薬剤はみら れず, 70〜89\%の株が感性を示した薬阂は GM, NA, DKB で, ABPC, CER, CP, TC, KM には 70〜80\%の株が耐性であり，EM，CL には全て の株が耐性であつた。

5）Pr. morganii：高い感性率を示した薬剤は 
なく, 70〜89\%の株が感性を示した薬剤は $\mathrm{GM}$, $\mathrm{DKB}, \mathrm{NA}$ で, $\mathrm{GM}>\mathrm{DKB}=\mathrm{NA}$ の感性順を示し, TC, ABPC, CER, CP, KM には40〜60\%の株 が，EM，CL には全ての株が耐性であつた。

6）Pr. rettgeri : 70\%以上の感性を示した薬剤 はなく， GM，DKB，NA に 40〜 50\%が耐性, ABPC，CER，CP，TC，KM に60 80\%が耐性, EM，CL には全ての株が耐性であつた。

7) Pr. inconstans : 高い感性率を示した薬剤は なく，70８9\%の株が感性を示した薬剤は GM， NA で, CP, TC, KM, DKB には40〜50\%の株 が耐性，ABPC，CER には80〜90\%が耐性，EM， CL には全ての株が耐性であつた。

8）Ps. aeruginosa：高い感性率を示した薬剤 は $\mathrm{GM}, \mathrm{DKB}, \mathrm{CL}$ で, CP, TC，KM には60〜 85\%の株が耐性，ABPC，CER，EM，NA には全 ての株が耐性であつた。

9） Str. faecalis：高い感性率を示した薬剤は $\mathrm{ABPC}$ のみで, CER, EM, CP, TC, GM には40 〜 50\%の株が耐性, DKB には75\%が耐性, KM, CL，NA には全ての株が耐性であつた。

8. 抗生物質投与による尿中細菌の変化

尿路感染症で治療を必要とした症例のうち56例 について，抗生物質投与による菌種沶よび菌数の 変化を非投与例と比較した(Table 7). 主な使用 薬羭は $\mathrm{ABPC}, \mathrm{KM}, \mathrm{DKB}$ である。な菌数の 変化がみられたもののうら，菌数がミ105/ml か ら $10^{2} / \mathrm{ml}$ 以下に減少した場合のみを菌数の 減少 例とした。 まず非投与群（23例）では，1 カ月後 の細菌検査で培養陰性となつた例はみられず,

Table 7 Effect of antimicrobial therapy on the microorganisms of urine

\begin{tabular}{|c|c|c|c|c|}
\hline & \multirow[b]{2}{*}{$\begin{array}{l}\text { Non-therapy } \\
\text { Group }\end{array}$} & \multicolumn{3}{|c|}{ Therapy group } \\
\hline & & \multicolumn{3}{|c|}{$\frac{\text { duration of therapy (days) }}{1-3} \frac{6-8}{10-14}$} \\
\hline No. of cases & 23 & 9 & 27 & 20 \\
\hline Negative : culture & 0 & 0 & $5(19 \%)$ & $9(45 \%)$ \\
\hline Change of organism* & $3(13 \%)$ & $3(33 \%)$ & $7(26 \%)$ & $6(30 \%)$ \\
\hline No change & 1 & 1 & 3 & 1 \\
\hline of organism** B & 19 & 5 & 12 & 4 \\
\hline
\end{tabular}

* microbisme selectionne et substitue, ** the same bacterial Apecies that were isolated at the beginning of the therapy,
bacterial cell counts
3 例 $(13 \%)$ )に菌種の変化（菌交代現象）をみた。 残り20例は菌種の変化はなく同一菌種が分離され たが，1例 $(4.3 \%)$ にのみ菌数の減少がみられ た.つぎに投与群をみると，投与後に培養陰性と なつた例は $1 \sim 3$ 日投与では $0 ， 6 〜 8$ 日投与で 5 例 $(18.5 \%) ， 10 \sim 14$ 日投与で 9 例 (45\%) で, 投与期間に比例して増加する傾向がみられた。 又 菌交代現象の 発現頻度は各々の投与期間で 3 例 $(33 \%) ， 7$ 例 $(26 \%) ， 6$ 例 (30\%) であり，投 与日数による差は殆んどみられなかつた. 一方菌 種の変化のない例は各期間で各々 6 例 $(67 \%)$, 15 例 $(56 \%) ， 5$ 例 $(30 \%)$ にみられ投与日数に したがつて減少する傾向がみられた。これらのら ち 1 例 $(11 \%), 3$ 例 $(11 \%), 1$ 例 $(5 \%)$ は菌 数の減少を伴つていた。

つぎに上記56症例のうち菌交代現象のみられた 例を含めた 4 症例について，抗生物質投与前後の 菌の消長和よび治療経過を示す。

[症例 A : 64歳, 女性] Fig. 6

臨床症状を伴つた歩行困難な脳血管害後遺症例 で，尿検査の結果，尿中に白血球 $(+)$ と $10^{5} / \mathrm{ml}$ 以上の E. coli を認めたため, 薬剤感受性試験 で感性 (H) を示した $\mathrm{ABPC}$ を $1 \mathrm{~g} \times 7$ 日間筋肉

Fig. 6 Microbiological course of patients with UTI

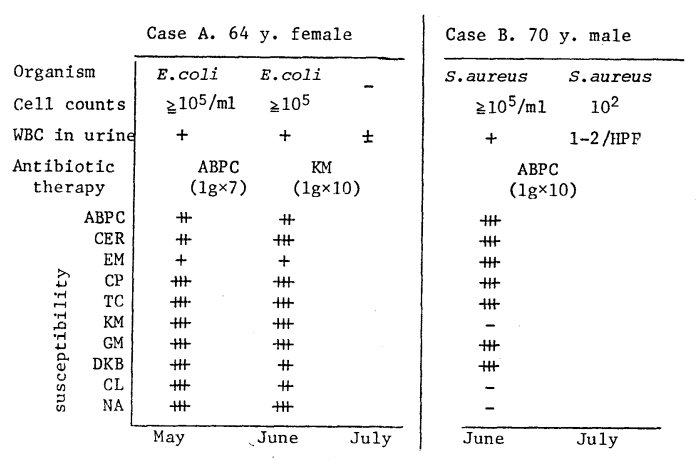

内注射した. 1 カ月後の検査で治療前の菌種, 菌 数とも変化なく， $\mathrm{KM}$ を $1 \mathrm{~g} \times 10$ 日間笳肉内注射 した。更に 1 力月後の検查では，尿中に白血球 （土）を認めたが，細菌は陰性となり，症状も消 失し治癒した。 
〔症例 B : 70歳, 男性] Fsg. 6

臨床所見から尿路感染症を疑わせた寝たきりの 脳血管障害例で, 尿検査の結果, 尿中に白血球 （卅）と $10^{5} / \mathrm{ml}$ 以上の Staph. aureus を認めたた め， $\mathrm{ABPC}$ を $\lg \times 10$ 日間投与した。 1 力月後の検 查で白血球 $(1-2$ /毎視野) となり Staph. aureus が $10^{2} / \mathrm{ml}$ 認められたものの, 臨床症状なく治癒に 至つた。

[症例 C : 81歳, 女性] Fig. 7

尿検査所見から尿路感染症を疑わせた演たきり の脳血管障害例で 2 カ月間にわたり，常に尿中に 白血球 (卅) と $10^{5} / \mathrm{ml}$ 以上の $\mathrm{Str}$. faecalis を認 めたため, 薬剤感受性試験で感性 (卅) を示した $\mathrm{ABPC} 1 \mathrm{~g} \times 7$ 日間投与した 1 カ月後の検査で白 血球は土に減少してたものの, ABPC に耐性の En. cloacae が $10^{5} / \mathrm{ml}$ 以上認められたため, En. cloacae に感性 (卅) の KM $1 \mathrm{~g} \times 10$ 日間筋肉 内注射した。翌月の検査では, 白血球土と, 治療

Fig. 7 Microbiological course of a patient with UTI

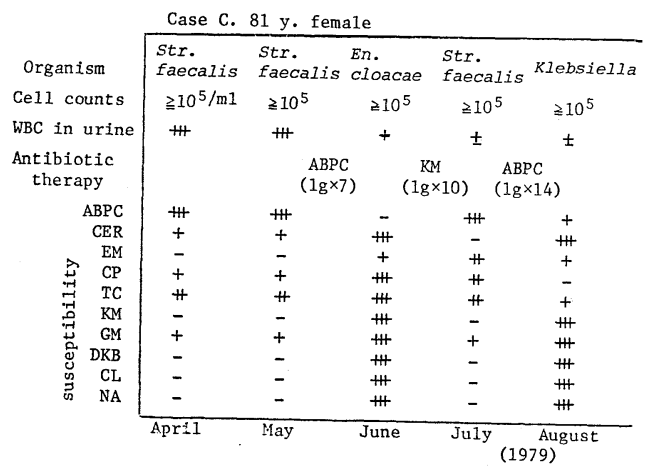

前にみられた KM に耐性の Str. faecalis を105 $\mathrm{ml}$ 以上認めた. さらに Str. faecalis に $\mathrm{ABPC}$ を $\lg \times 14$ 日間筋肉内注射して 1 力月後に得られた 結果は白血球（士）とABPC に耐性の Klebsiella が $10^{5} / \mathrm{ml}$ 以上みられ, 初回の抗生剂投与後, 尿 中白血球に減少がみられたが, 細菌数には変化が みられず，菌種の交代を繰り返した1例である。

[症例D：79歳, 女性] Fig. 8

脳血管障害後遺症例で, 尿中に白血球 (W) と,
Fig. 8 Microbiological course of a patient with UTI

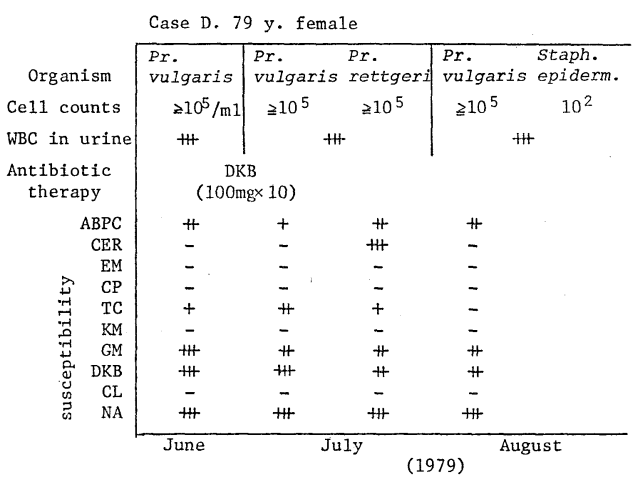

$\geqq 10^{5} / \mathrm{ml}$ の Pr. vulgaris を認め, DKB を $100 \mathrm{mg}$ 10日間投与した. 1 カ月後の尿検査で, 白血球 （卅）と DKB に耐性の Pr. vulgaris と, 感性の Pr. rettgeri $10^{5} / \mathrm{ml}$ 以上認めた. 更に 1 カ月後 の観察で DKB に感性のPr- vulgaris と staph. epidermidis $10^{5} / \mathrm{ml}$ 認め, 治療効果がみられず 菌種の交代ないし同一菌種の感受性の変化が推測 された例である。

9. 尿路感染症例の臨床所見特よび検查所見

1) 臨床所見々血液理化学的検査所見

尿路感染症以外に感染症を合併していない例 で，比較的軽度の脳血管障害後遺症例60例を対象 に，同地域の健常老年者と比較した．尿路感染症 例のらち残尿感，排尿痛などの自覚症状を訴えた のは 3 例 $(5 \%), 38^{\circ} \mathrm{C}$ 以上の発熱は 1 例 $(2 \%)$ にすぎなかつた。血液理化学的検査所見では, CRP 3+以上の例は 2 例 (4\%) であつた。白血 球数, 総タンパク濃度, 血清 $\gamma$-グロブリン值で は，尿路感染症群と健常群との間に有意差はみら れなかつた。

2）尿検査所見

カテーテル採取尿で，沈渣鏡検と尿培養を同時 に実施し, 沈椬中に白血球を毎視野 1 個以上認め た250例の成績を Table 8 に示す.白血球土群 (42 例) の細菌尿出現頻度 ( $\left.\geqq 10^{5} / \mathrm{ml}\right)$ は $16.7 \%,+$ 群(47例) では76.6\%. \#群 (45例) では $86.7 \%$, 卅群 (116例) では $94.0 \%$ と白血球数と培養陽性 頻度は比例した。 
Table 8 Relationship between leucocytes and bacterial cell counts in urine

\begin{tabular}{c|cccc}
\hline \multirow{2}{*}{$\begin{array}{l}\text { Bacteria1 } \\
\text { cell counts }\end{array}$} & \multicolumn{4}{|c}{ WBC in urine } \\
\cline { 2 - 5 } & \pm & t & H & H \\
\hline 0 & $20(47.6 \%)$ & $3(6.4)$ & $1(2.2)$ & 0 \\
$<10^{5} / \mathrm{m} 1$ & $15(35.7)$ & $8(17.0)$ & $5(11.1)$ & $7(6.0)$ \\
$\geqq 10^{5} / \mathrm{m} 1$ & $7(16.7)$ & $36(76.6)$ & $39(86.7)$ & $109(94.0)$ \\
\hline tota1 & 42 & 47 & 45 & 116 \\
\hline
\end{tabular}

Table 9 Relationship between microorganisms and leucocytes in urine

\begin{tabular}{|c|c|c|c|c|}
\hline Organism & $\begin{array}{c} \pm \\
\mathrm{n}=\end{array}$ & $\begin{array}{r}+ \\
47\end{array}$ & $\begin{array}{l}\# \\
45\end{array}$ & $\begin{array}{c}\text { \# } \\
116\end{array}$ \\
\hline Staph.aureus & $2.4 \%$ & 2.1 & 2.2 & 6.9 \\
\hline Staph.epidermidis & 14.3 & 4.3 & 2.2 & 4.3 \\
\hline$\alpha-$ Streptococcus & 2.4 & 2.1 & & 1.7 \\
\hline$\beta$-Streptococcus & 2.4 & 4.3 & 2.2 & 1.7 \\
\hline$\gamma$-Streptococcus & 4.8 & 2.1 & & 2.6 \\
\hline Str.faecalis & 19.0 & 17.0 & 13.3 & 10.3 \\
\hline Corynebacterium & 9.5 & 10.6 & 11.1 & 6.9 \\
\hline E.coli & 9.5 & 53.2 & 42.2 & 36.2 \\
\hline Klebsiella & 7.1 & 12.8 & 15.6 & 26.7 \\
\hline Enterobacter cloacae & & 2.1 & 2.2 & 3.4 \\
\hline Citrobacter & & & & 1.7 \\
\hline Pr.mirabilis & 2.4 & 14.9 & 31.1 & 50.0 \\
\hline Pr.vulgaris & & 6.4 & 8.9 & 24.1 \\
\hline Pr.morganii & & 4.3 & 6.7 & 13.8 \\
\hline Pr.inconstans & & 2.1 & 2.2 & 5.2 \\
\hline Ps.aeruginosa & & 4.3 & 4.4 & 8.6 \\
\hline others & & 4.3 & 4.4 & 6.9 \\
\hline negative cultures & 47.6 & 6.4 & 2.2 & 0 \\
\hline $\begin{array}{l}\text { Average No. of } \\
\text { organisms ( / case) }\end{array}$ & 0.74 & 1.47 & 1.49 & 2.02 \\
\hline
\end{tabular}

又, 尿中白血球数と分離菌種との関連 (Table 9) をみると, 白血球士群で Str. faecalis, staph. epidermidis を主体とするグラム陽性球菌の分離 頻度が高かつたのに比べ，十群，卅群，卅群では E. coli，Klebsiella，Proteus 群を主体とするグラ ム陰性桿菌の分離頻度が高く, 平均分離菌種数は

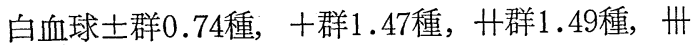
群2.02種と, 白血球土群に比べて,,++ , 卌群 で極めて有意の増加を認めた。（Mean士S.D.の 差の検定で $\mathrm{p}<0.0005)$, 又尿中白血球数と主要細 菌の分離頻度との関係をみると, Fig. 9 亿示す如 く, Str. faecalis と E. coli は白血球十群に多かつ たが, Klebsiella, Pr. mirabilis, Pr. vulgalis, Pr. morganii は白血球卅群に多い傾向がみられた。

\section{0，尿路感染症患者の胵内細菌}

本年度新たに寝たきりの難治性女性患者46名を 選び尿細菌培湌を行なつた。分離菌種は1979年度 と著明な変化がなかつたが，これらの患者のう ち尿路感染症の経過が比較的長い25名に対し, 粪 便以外の污染源をみるため腟内の細菌培養を試み
Fig. 9 Relationship between organisms and leucocytes in urine

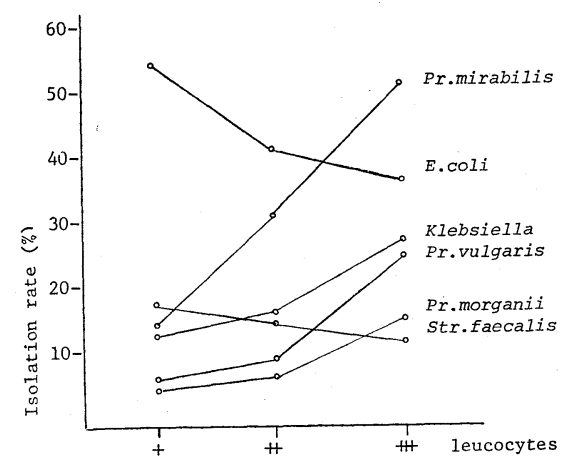

Table 10 Numbers and percentage of organisms isolated from 25 vaginal cultures

\begin{tabular}{lc|cc} 
Organism & $\begin{array}{c}\text { No.of } \\
\text { strains }\end{array}$ & $\begin{array}{c}\text { Isolation } \\
\text { rate }(\%)\end{array}$ & $\begin{array}{c}\text { Average No. } \\
\text { of organism }\end{array}$ \\
\hline Aerobe & 147 & 83.5 & 5.89 \\
cocci & 51 & 29.0 & 2.04 \\
rods & 96 & 54.5 & 3.84 \\
\hline Anaerobe & 24 & 13.6 & 0.96 \\
\hline Fungus & 5 & 2.8 & 0.20 \\
\hline
\end{tabular}

Table 11 Frequency of occurence of organisms isolated from 25 vaginal cultures

\begin{tabular}{|c|c|c|c|}
\hline Organism & $\begin{array}{l}\% \text { of } \\
\text { cultures } \\
\text { positive* }\end{array}$ & $\begin{array}{l}\text { isolation } \\
\text { rate( } \%)\end{array}$ & \\
\hline Staph.aureus & 20 & 2.8 & \multirow{7}{*}{$51(29.0)$} \\
\hline Staph.epidermidis & 32 & 4.5 & \\
\hline Strepto.faecalis & 48 & 6.8 & \\
\hline$\alpha$-Streptococcus & 48 & 6.8 & \\
\hline B-Streptococcus & 16 & 2.3 & \\
\hline non-hemolytic strepto. & 20 & 2.8 & \\
\hline other cocci & 20 & 2.8 & \\
\hline Corynebacterium sp. & 76 & 10.8 & \multirow{9}{*}{$96(54.5)$} \\
\hline E.coli & 64 & 9.1 & \\
\hline Klebsiella & 40 & 5.7 & \\
\hline Pr.mirabilis & 52 & 7.4 & \\
\hline Pr.morganii & 40 & 5.7 & \\
\hline Pr.inconstans & 20 & 2.8 & \\
\hline Ps.aeruginosa & 44 & 6.3 & \\
\hline$G(-) G N R * *$ & 24 & 3.4 & \\
\hline other rods & 24 & 3.4 & \\
\hline Peptococcus & 20 & 2.8 & \multirow{5}{*}{$24(13.6)$} \\
\hline Peptostreptococcus & 16 & 2.3 & \\
\hline Propionibacterium & 28 & 4.0 & \\
\hline Lactobacillus & 20 & 2.8 & \\
\hline other anaerobes & 12 & 1.7 & \\
\hline Candida & 16 & 2.3 & \multirow{2}{*}{$5(2.8)$} \\
\hline other fungus & 4 & 0.6 & \\
\hline
\end{tabular}

た。その結果 Table 10に示すよらに好気性菌147 株，嫌気性菌24株，真菌 5 株が分離された。平均 分離菌種数は 8.05 種（好気性菌 5.89, 嫌気性菌 0.96, 真菌0.20)であつた. 分離菌の内訳を Table 
11に示したが，胵内には腸内細菌群を主体とする 多種類の細菌が分離され, opportunistic pathogen と考学られるブドウ糖非発酵グラム陰性桿菌 る $3.4 \%$ に分離された。

\section{IV. 考 察}

尿路感染症の発生頻度は年齢, 性別によつて異 なり ${ }^{28)}$, 基礎疾患の重症度とも大いに関連のあ ることは周知の通りである。

著者は主に脳血管障害後遺症患者の治療を目的 とした施設に長期入院中の患者を対象とし，自覚 症状および尿検查所見から尿路感染症が疑われた 例について臨床細菌学的検討を行ない, 若干の知 見を得た。

\section{1. 尿路感染症の原因菌}

著者が 過去 6 年間に638例 の老年者から得た尿 路感染症原因菌の分離状沉を, 同様の老年者を対 象とした猪狩 ${ }^{1)}$ ，島田 ${ }^{2)}$ ，McMillan ${ }^{4)}$ らの成績と 比較すると（Table 12）, 分離菌は多種に及び菌

Table 12 Bacteria isolated from urine of the aged

\begin{tabular}{l|rccc}
$\begin{array}{c}\text { Reporter } \\
\text { Organism }\end{array}$ & Okada & $\begin{array}{c}\text { Igari } \\
\text { et al }\end{array}$ & $\begin{array}{c}\text { Shimada } \\
\text { et al }\end{array}$ & $\begin{array}{c}\text { McMillan } \\
\text { et al }\end{array}$ \\
\hline Staphylococcus & 6 & 4 & 5 & 0 \\
Str.faecalis & 8 & 11 & 16 & 8 \\
E.coli & 26 & 36 & 17 & 38 \\
Klebsiella & 13 & 9 & 16 & 28 \\
Proteus & 34 & 23 & 21 & 18 \\
Ps.aeruginosa & 8 & 2 & 13 & 8 \\
others & 5 & 15 & 12 & 0 \\
\hline
\end{tabular}

種による分離頻度の差は認められたが，全体的に は類似した成績であつた。 又混合感染例が多く, その頻度は著者の $44 \%$ とほぼ同様の成績で，分離 菌種の多様性と混合感染の多いことが老年者尿路 感染症の一つの特徵2) と考えられた。

2. 分離菌種の年次推移々その背景

過去 6 年間の分離菌種の変動をみると，1974年 ではインドール陰性 Proteus (Pr. mirabilis) $>$ E. coli $>$ Klebsiella>インドール陽性 Proteus の順 であつたが，1975〜1976年には E.coli>Pr. mirabilis>インドール陽性 Proteus, 1977年には E. coli>インドール陽性 Proteus, 1978年にはイン ドール陽性 Proteus $>$ E.coli となり, 年毎にイン
ドール陽性 Proteus の分離頻度に増加傾向が認め られたが，その主な理由は化学療法剤の種類お よび使用量の 変化 ${ }^{9)}$ と, 耐性株の増加による菌 交代現象 ${ }^{10)}$ にるるのと考兄られた. そこで化学 療法剂の使用状況をみると，1974年度迄に使用頻

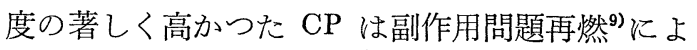
り1976年度以降は全く使用されなくなり，これに 代わつて $\mathrm{ABPC}, \mathrm{DKB}, \mathrm{CER} の$ 使用頻度が増加 した。次に薬凧感性率の年次推移をみると, CP, ABPC，DKB の3剤に一定の傾向がみられた。す なわち CP は.coli, Klebsiella, インドール陽 性 Proteus の各菌種で1976年から1979年にかけて 年々の感性化の傾向がみられたが， ABPC, DKB では1976年から1979年にかけて徐々に耐性化の傾 向を示した。このことは前述の抗生物質使用状況 およびインドール陽性 Proteus 属の台頭と大いに 関連あるものと考えられた。

3. 歩行状態と尿路感染症発生頻度和よび細菌 分離状況

脳血管障害後遺症で長期入院中の老年者に打け る尿路感染症の発生頻度は, 歩行可能患者で14.6 $\%$, 歩行困難患者で $23.1 \%$ ，寝たきり 老年者で $69.3 \%$ ，寝たさり老年患者に有意の増加がみら れた。菌種別にみると, 歩行可能特よび歩行困難 患者では E.coli を主としたグラム陰性桿菌が65 \%を占めたのに対し，寝たきり患者では Proteus を主とした多種に执よぶグラム陰性桿菌の分離率 が95\%を占め, 糞便による污染との関連の強いこ とが示唆された。

一方, 歩行不能患者（寝たきり患者）飞括ける 膝関節運動機能と尿路感染発生頻度特よび細菌分 離状況をみると, 膝関節運動機能障害の程度が増 すにつれて尿路感染症の発生頻度が高く, 分離菌 の内訳では軽度拘縮群に E.coli の分離頻度が高 いのに比し, 重度麻痺群では Proteus の分離頻 度が高く, 運動障害の重症度と分離菌種に関連性 があり，薬剤耐性率の高いProteus の分離され る重度麻痺群で治癒が遷延化し, 難治性となる傾 向がみられた。

4. 菌種別薬剤感性率について 
1979年度の分離菌のらち分離頻度の高いE.coli, Proteus について，著者の成績を諸家のそれと比 較すると， E. coli については従来 $\mathrm{KM}$ が最も 感性であるとされていたが711121)，一方 GM が 優れているとする報告もある ${ }^{213)}$ ，老年者を対象 とした島田ら ${ }^{2)}$ はM 99\% (感性率), CL 97\%， CER 77\%, KM 71\%, NA 57\%, ABPC 39\%の成 績を示し，猪狩らは 88.9\% CER 89\%, NA 80.5\%, SM, TC 69.4\% と 報告している，これらは著者の成績の $\mathrm{CL}, \mathrm{GM}$ ， $\mathrm{NA}, \mathrm{DKB}(97 \sim 99 \%), \mathrm{KM}, \mathrm{CER}, \mathrm{CP}, \mathrm{TC}(77$ 〜 86\%), $\mathrm{ABPC}(63 \%)$ と差が認められたが， これは入院患者層, 対象患者の基礎疾患や抗生剂 使用頻度の違いなどによるものと考兄られた。

Proteus については, E.coli 同様乃ミノグリコシ ド剤に感性率が高いとする報告がみられるが ${ }^{13)}$, 耐性株は徐々に増加している ${ }^{14)}$. 周知の如く Proteus は菌種による感受性の差が著しく ${ }^{15) 16)}$, 著 者の成績ではインドール陽性 Proteus で ABPC, $\mathrm{CER}, \mathrm{KM}, \mathrm{CP}, \mathrm{TC}$ 飞耐性率が高かつた。この ようにインドール陽性 Proteus が各種薬剤に多剤 耐性であることと，耐性率の度合の高い $\mathrm{ABPC}$, $\mathrm{CER}, \mathrm{KM}$ などの使用頻度が高いことなどが本 菌群の分離頻度の増加及び難治性の主な理由と考 えられた。

5. 尿路感染症例の臨床所見和よび検査所見

脳血管障害後遺症例にみられる尿路感染症は無 症候性であること ${ }^{17)-19)}$ が多く，著者の調査でも 臨床所見は殆ど見られず，健常群との間に有意の 差を認めなかつた。一方尿検査所見では，尿中に 白血球を多数認めた例に $\geqq 10^{5} / \mathrm{ml}$ の細菌尿 ${ }^{20)}$ 示す傾向が強々, 分離菌も 2 種以上の mixed culture であることが多かつた. 又尿中白血球多数例 からは Proteus 群の分離頻度が高く, 尿 $\mathrm{pH}$ も Proteus の発育に好適な強アルカリ性であること などが示され，これらは治療に際し留意すべき事 項と考觉られた。

6. 化学療法による尿中細菌の変化について

尿路感染症の治療には, 起炎菌に感性を示す化 学療法剂の中から適切な薬剂を選択し, 培養陰性
となるまで投与を続ける必要のあることは言うま でもない，特に老人では無症候性の場合が多く，

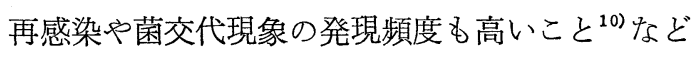
から, 治療効果の判定にはより慎重を期する必要 がある.今回56例の患者に対して抗生物質投与後 の菌の変化を検討した結果では, 投与後培養陰性 となつた割合は予想されたとおり投与期間の長い 程高率であつた. 又菌交代現象の発現頻度は, 投 与日数に関係なく約30\%にみられた. 治療効果を 菌の消長のみで判定することはできないが，培養 陰性例および菌交代を伴わず菌数の減少した例を 治療に反応した例と考劣ると，両者に含まれる例 数は $1 \sim 3$ 日投与群で $1 / 9(11.1 \%) ， 6 \sim 8$ 日投 与群で 8/27 (29.6\%)，10１4日投与群で 10/20 （50\%）となり，10１4日投与群に最もよい治療 効果が期待された. 投与期間を更に延長すれば培 養陰性率の増加が期待されたが, 老人では化学療 法剤の副作用の発現率が有意に高く ${ }^{2)}$, 腎機能障 害などを惹起する危険性があることや，化学療法 剂の投与により耐性菌や菌交代現象の発現を助長 する持それもあることなどから，長期投与は極力 避ける方がよいと考兄られた。これらのことから 原則的には化学療法剤の投与は必要最低限にとど め, 化学療法が必要な場合は耐性菌の出現や菌種 の交代に十分留意し，混合感染の場合には多剤併 用なども考慮する必要があると考光られた.

7. 女性の尿路感染症例に括沙腔内細菌㙚と の関係について

上記の調查成績から分離菌種に多剂耐性菌の多 いことが, 治癒の遷延化や再発, 菌交代を惹起す る主原因と考えられたが，更に尿以外の污染源に ついて検討を加えた．対象患者の大部分がオムッ 使用者であり，尿路系が糞便污染を受けやすいこ と ${ }^{21)}$ は言うまでもない，著者の成績でも分離菌の 多くは糞便内に常在しているグラム陰性桿菌であ り，翼便污染との関連性の強いことが推測された が，尿特よび䔬便中の同一菌種の薬剤感受性に差 のある場合があり，尿路感染と糞便污染を一元的 に結びつけることは困難と考えられた。そこで対 象患者の大部分は女性であることから，便と尿に 
介在するものとして 腔内細菌を調べたわけであ る. 今回は 25 名の難治性尿路感染症患者について 検討したが，平均 8 菌種にも及ぶ多種類の細菌が 分離され, 分離菌の内訳をみると,グラム陰性桿 菌が全体の約 $1 / 2$ 占めて拈り，同時に実施した 尿の細菌培養で分離された菌の大部分がグラム陰 性桿菌であつたことから，腟から尿への污染が 推測された. 又胵内にはいわゆる normal flora ${ }^{22)}$ を含めて opportunistic pathogen ${ }^{23)}$ と考えられ る菌種が多数含まれて扣り，これらの菌による opportunistic infection ${ }^{24)}$ や terminal infection $の$ 可能性を考慮する必要があると思われた．腟内分 離菌の薬剤感受性や，抗生物質投与後の菌種，菌 数の変動については検討しなかつたが，ブドウ糖 非発酵菌，嫌気性菌などが胵内細菌叢に含まれて いることは興味深い。このことから女性の難治性 尿路感染症患者に対しては局所の清拭と同時に胵 内洗浄なども必要であることが示唆された。

\section{V. 結 語}

脳血管障害後遺症 で 長期入院中の 患者尿から は，多種に扣よぶ細菌が分離され，二種以上の混 合感染を約半数に認めた。更にこの傾向は下肢運 動機能障害者, 特に重度麻痺群に強かつた。菌種 別では E.coli や多剂耐性のインドール陽性 Proteus の分離頻度が高かつた。

治療に際しては，而性菌の出現や菌交代を十分 考慮した上で適切な化学療法剤を選択し，菌が完 全に消失するまで投与を続ける必要があり，又寝 たきりのオムッ使用患者では局所を清潔にし再感 染を防止すると共に，女性では腟内洗浄も心懸け る必要があると考えられた。

謝辞稿を終光るに当り，本研究に多大の御援助をい ただいた愛生会多摩成人病研究所, 牛尾盛保, 牛尾博昭 博士，橴谷正行検查室長に感謝します。

\section{文献}

1) 猪狩淳, 林康之, 村瀬 修: 老年者の尿 路感染症について一老人ホーム入所例飞お梳 る尿路感染症 の臨床細菌学的検討一. 日老医 会誌，12：291-295, 1975.

2）島田 鳘, 稲松 孝思: 老人 の感染症. 総合 臨床, $23: 1753-1757,1974$.
3) Cape, R.D.T.: Management of Bacteriuria in the Elderly Female, in Urinary Tract Infection, eds Brumfitt, W., and Asscher, A.W., Oxford Univ. Press. London, 1973, p. 223236.

4) MaMillan, S.A.: Bacteriuria of Elderly women in Hospital: Occurrence and Drug Resistance. Lancet, 11: 452_455, 1972.

5) Curtis, J.R.: Urinary Tract Infection in the Elderly Woman. J. Geront., 22: 502-509, 1967.

6) Kaitz, A.L. \& Williams, E.J.: Bacteriuria and Urinary Tract Infections in Hospitalized Patients. New Eng. J. Med., 262(3): 425430, 1960.

7) 東福寺 英之, 吉沢一太 : 尿路感染症の起因 菌およびその薬剤耐性分布。臨床泌尿，24： 561-571， 1970.

8) Bush, I.M., Orkin, L.A. \& Winter, J.: An Eleven-year Study of Urinary Bacterial Cultures in a Total In-Patient Hospital Population. J. Urol., 94: 168-171, 1965.

9) 藤井 良和 : 化学療法剂使用の現況. 最新医 学, 32 (8) : 1439-1445, 1977.

10）藤村 宣夫，湯浅 正明，上間 健造 : 尿路感 染症における菌交代現象。西日本泌尿器科, 40 (3) : 360-368, 1978.

11) 王丸鴻一：尿路感染症分離菌の薬剤耐性之そ の年次的変遷。皮と泌，30：617-623，1968。

12) 加藤篤二, 浜田邦彦, 白石恒雄 : 尿路感染症に 於ける薬剤耐性とその療法. 泌尿紀要, 8： 235一243, 1962 .

13）江田 享, 神水陽一郎, 西平陽子, 松岡俊介 : 尿路感染症の起炎菌とその薬剤感受性.臨床 泌尿，27：155-161，1973.

14) 島田檠，小林章夫, 岩間注美ほか：ゲンタマ イシン耐性菌の研究 (第 2 報). Chemotherapy, $24: 1506-1510,1976$.

15）真下啓明：最近の感染症とその治療の問題点. 最新医学, 31 （7）：1253-1257. 1976,

16) 小酒井望 : 病原菌の化学療法剤感受性の現沉. 小児科，16（2）：1203-1212，1975,

17) Kunin, C.M.: Asymptomatic bacteriuria. Ann. Rev. Med., 17: 383-406, 1966.

18）松本文夫：老年者の腎，尿路感染症. Geriatric Medicine, 10: 136-140, 1972 .

19) Wolfson, S.A., Kalmanson, G.M., Rubini, M.E. \& Guze, L.B.: Epidemiology of Bacteriuria in a Predominantly Geriatric Male Population. Amer. J. Med. Sci., 250: 168173, 1965.

20) Kass, R.H., et al.: The Significance of Bacteriuria in Preventive Medicine, in Pro- 
gress in Pyelonephritis, ed. Kass, E.H., Davis, F.A. \& Co., Philadelphia, 1969, p. $3-10$.

21）伊藤機一：老年者に打ける褶鹰創面からの分 離細菌に関する研究. 日本老会誌, $15 ： 471$ 一 484, 1978.

22) Corbishley, C.M.: Microbial flora of the vagina and cervix. J. Clin. Prthol., 30: 745-
748, 1977.

23) Prier, J.E. \& Friedman, H.: Opportunistic Pathogens, University Park Press, Baltimore, 1974 , p. $19-35$.

24) 螺良英郎, 熊谷久治郎注か: Opportunistic Infection, 感染之臨床免疫学の 進歩, 近代出版, 1978, p. $142-161$.

A Clinical Microbiological Study on Urinary Tract Infection of the Aged with

Sequelae of Cerebrovascular Disorders

Jun OKADA

Department of Clinical Pathology, Juntendo University School of Medicine

The old bedridden patients, especially in combination with the sequelae of cerebrovascular disorders, are frequently suffered from urinary tract infections (UTI). This paper reviews the clinical microbiological study on UTI of the aged. 638 mean aged $75 \mathrm{yr}$ bedridden patients (159 male, 479 female), who admitted to Koseiso Hospital, Tama Institute for Adult Diseases, between 1974 and 1979, because of the sequelae of cerebrovascular disorders were studied for the purpose of observing annual incidence of microorganisms. Samples for quantitative culture examinations were obtained by urinary catheter, and in some female cases, vaginal microbilological examinations were also performed. Results were as follows :

1) A total of 1901 strains of microorganisms were isolated from 1267 cultures during six years observation. The most important infecting organisms were Staph.aureus, E.coli, Klebsiella, indole positive Proteus groups. Comparing the annual frequency of the organisms, there was the decrease in the proportion of Staph.aureus, Klebsiella, Pr.mirabilis in the year from 1976 to 1979, whereas E.coli, indole positive Proteus groups and Ps.aeruginosa were increasing year by year, especially very striking was the rise of the percentage of indole positive Proteus groups, which were found in 18\% of samples during 1974, in 26\% during 1975, in 39\% during 1978, and in 34\% during 1979. Another interesting features is that very often mixed infections with these organisms were observed.

2) In annual change of antimicrobial susceptibilities against commonly used antimicrobials to the isolates, the rise in frequency of antimicrobial resistant strains was observed year by year, especially in the predominant isolates of Proteus groups.

3) Among 56 cases of UTI, 8 cases (14.3\%) presented a change of the original bacteria after a course of antibacterial treatment.

4) A total of 25 vaginal specimens were collected from female bedridden patients. In vaginal cultures, numorous species were recovered. Many of them were gram negative rods, but other bacteria of low pathogenicity, so called "opportunistic pathogens" such as glucose nonfermentative gram negative rods, anaerobes and fungi, were also isolated.

These results indicated that many cases of UTI of the aged were complicated type of infection and sometimes took longterm course with change of spectrum of bacteria, and was often in combination with mixed infection due to resistant type of oragnisms. These facts represent a serious problem in antimicrobial chemotherapy. Effective chemotherapy, of course, seems to be essential condition for a treatment of these infections. In addition to this, good nursing care, maintenance of hygine including urinary bladder and vagina are also important measures for prevention and treatment for these types of UTI. 